\title{
Characteristics of the root system in two Brazilian upland rice varieties which exhibit contrasting behavior towards drought tolerance
}

\section{Características radiculares de duas variedades brasileiras de arroz de terras altas contrastantes quanto à tolerância ao estresse hídrico}

\author{
Leandro Martins Ferreira ${ }^{1 *}$; Cristiana Maia de Oliveira ${ }^{2}$; Leilson Novaes Arruda ${ }^{3}$; \\ Renan Pinto Braga ${ }^{4}$; Orlando Carlos Huertas Tavares ${ }^{4}$; Sonia Regina de Souza ${ }^{5} \dagger$; \\ Manlio Silvestre Fernandes ${ }^{6}$; Leandro Azevedo Santos ${ }^{6}$
}

\begin{abstract}
Highlights:
Lateral root emission contributes to the mechanism of drought escape in Catetão.

Catetão increased the root number at $60-90^{\circ}$ angle under drought stress.

Membrane integrity was less compromised during drought stress in Catetão.

Ratio of deep rooting can be used to select tolerant genotypes to the drought stress.
\end{abstract}

\begin{abstract}
Root system architecture plays a fundamental role in the adaptation of rice to environments subjected to abiotic stresses. This study aimed to characterize the root architecture and morphology of two Brazilian upland rice varieties which display contrasting behavior towards drought tolerance: the tolerant Catetão and susceptible Mira varieties. Two experiments were carried out under greenhouse and growth chamber conditions. The experimental design was completely randomized in a $2 \times 2$ factorial scheme (varieties $\times$ drought stress conditions) with four replicates. Rice varieties were subjected to control and drought conditions for 14 days. Drought stress was applied either by withholding water until the desirable soil tension was achieved or by addition of $20 \%$ polyethylene glycol 6000 (PEG) to the nutritive solution. After harvest, the dry weight, root architecture, as well as physiological and root features were assessed. Under drought stress, a higher root biomass was recorded in Catetão compared to Mira. A higher ratio of deep rooting (RDR) was observed for Catetão, while Mira remained stable in response to drought stress. The evaluated physiological features showed that the Catetão variety is less likely to compromise membrane integrity and lipid peroxidation during drought stress. Moreover, analyzed root features exhibited a significant increase in lateral root emission and root density for Catetão in response to drought treatment, which may be considered an important feature when selecting for superior genotypes.

Key words: Drought escape. Lateral roots. Root plasticity. Ratio of deep rooting.
\end{abstract}

1 Técnico de Laboratório, Instituto Federal de Educação, Ciência e Tecnologia de Mato Grosso do Sul, IFMS, Mato Grosso do Sul. MS, Brasil. E-mail: leandro.ferreira@ifms.edu.br

2 Prof ${ }^{a}$, IFMS, Mato Grosso do Sul, MS, Brasil. E-mail: cristiana.oliveira@ifms.edu.br

3 Analista, Companhia Nacional de Abastecimento, CONAB, ES, Brasil. E-mail: arrudaln@hotmail.com

4 Discentes, Curso de Doutorado do Programa de Pós-Graduação em Agronomia/Ciência do Solo, Universidade Federal Rural do Rio de Janeiro, UFRRJ, Seropédica, RJ, Brasil. E-mail: renanpbraga@gmail.com; ochtavares@gmail.com

5 Profa, Departamento de Química, UFRRJ, Seropédica, RJ, Brasil. E-mail: soniabq@ufrrj.br (in memorian)

6 Profs., Departamento de Solos, UFRRJ, Seropédica, RJ, Brasil. E-mail: manliosf@gmail.com; azevedo@ufrrj.br

* Author for correspondence 


\section{Resumo}

A arquitetura do sistema radicular exibe um papel fundamental na adaptação do arroz a ambientes sujeitos a estresses abióticos. Por esta razão, este estudo teve como objetivo caracterizar a arquitetura do sistema radicular e sua morfologia em duas variedades de arroz brasileiras de sequeiro contrastantes quanto à tolerância ao estresse hídrico, Catetão (tolerante) e Mira (suscetível). Foram realizados dois experimentos, o primeiro em casa de vegetação e o segundo em câmara de crescimento. O delineamento experimental foi inteiramente casualizado com quatro repetições em um esquema fatorial $2 \times 2$ (variedades x condições de estresse hídrico). As variedades de arroz foram submetidas a condições controle e estresse hídrico durante 14 dias. O estresse hídrico foi aplicado ao reduzir a lâmina d'água a tensão desejada no solo ou com a utilização de $20 \%$ de polietilenoglicol 6000 (PEG) na solução nutritiva. A massa seca, arquitetura do sistema radicular, características fisiológicas e características radiculares foram determinadas após a colheita. A variedade Catetão mostrou maior biomassa radicular comparada a Mira quando submetida ao estresse hídrico. Foi observado maior taxa de raízes profundas (RDR) na Catetão, enquanto a Mira permaneceu estável em resposta ao estresse hídrico. As características fisiológicas avaliadas mostraram que a variedade Catetão está menos sujeita a danos a integridade da membrana e peroxidação de lipídeos durante o estresse hídrico. Além disso, as características radiculares analisadas mostraram que a variedade Catetão apresentou um aumento significativo na emissão de raízes laterais e densidade radicular em resposta ao estresse hídrico, o que pode ser considerado como uma importante característica a ser selecionada em genótipos superiores.

Palavras-chave: Escape à seca. Plasticidade radicular. Raízes laterais. Taxa de raízes profundas.

\section{Introduction}

Rice (Oryza sativa L.) is considered to be the staple food crop of more than half of the world's population and is an important source of protein and carbohydrate, especially in developing countries (Bishwajit et al., 2013; Nakandalage et al., 2016). According to Seck, Diagne, Mohanty and Wopereis (2012), by the year 2035, approximately $26 \%$ increase in world rice production will be required to meet growing population demands.

Rice can be cultivated in different ecosystems: (a) rainfed system, where the water demand is supplied only by rainwater, (b) irrigated system, where the crop receives water in a controlled way, and(c) floodplain system, where the water supply is from a river. Rice is predominantly cultivated in flooded fields rather than in rainfed conditions; however, this scenario has been modified due to climatic change, with more rice being grown under rainfed conditions around the world (Tardieu, Draye, \& Javaux, 2017).

Crop productivity can be adversely influenced by a wide range of environmental factors. Abiotic stresses are the main causes of reduced crop growth and productivity, with drought, salinity, temperature, aluminum toxicity, soil acidity, flooding, pollution, and radiation being among the most frequent (Lawlor \& Cornic, 2002; Ortiz, Urbano, \& Takahashi, 2019). It is estimated that abiotic stresses can reduce crop productivity by up to $70 \%$, with drought considered to be one of the main abiotic factors limiting global food production, affecting approximately $64 \%$ of all arable land in the world (Cramer, Urano, Delrot, Pezzotti, \& Shinozaki, 2011).

Rice is particularly sensitive to drought stress and it is estimated that $50 \%$ of the rice production in the world is related either to the occurrence or absence of drought (Bouman, Peng, Castaneda, \& Visperas, 2005). Passioura (1997) defines drought as "an event in which plants show reduced growth or productivity due to a low soil water content or a large air humidity deficit". This event creates a greater energy demand for the plant's survival rather than for its production.

Drought resistance in plants can manifest as four stress-induced response types: (i) drought 
tolerance, i.e. the ability of cells and tissues to withstand a reduced water potential during a water deficit; (ii) drought avoidance, whereby plants are able to prevent the reduction of water in the tissues during the water deficit; (iii) drought escape, i.e. the ability of plants to complete their life cycle within the period of water availability, thus not being subject to a period of water deficit; (iv) drought recovery, whereby plants are able to resume growth and terminate their life cycle after a period of water deficit (O’Toole \& Chang, 1979).

Drought resistance based on these responses has been extensively studied in rice varieties (Henry, 2013). The drought escape mechanism is an important strategy for rainfed rice varieties. Their root system morphology and architecture can be favorable under conditions of low availability of nutrients such as nitrogen and in environments with excess of toxic aluminum (Lian et al., 2004).

Root system architecture and distribution are key determinants in the ability of a plant to uptake nutrients and water in order to support shoot growth in drought conditions (Suralta et al., 2018). It is generally believed that roots can sense changes in abiotic factors such as soil water status (Gao, Xie, Jiang, Wu, \& Niu, 2014), soil texture (Rogers et al., 2016) and nutrient composition (Kell, 2011).

Several studies have characterized the development of the root system, with respect to adventitious root formation, root lengthening, as well as lateral root and root hair development (Wu \& Cheng, 2014; Biscarini et al., 2016). In many agricultural systems, root system size and architecture are limiting factors in the growth and yield of plants, since they are responsible for determining the plant's ability to uptake water and nutrients (Paez-Garcia et al., 2015).

The present study aimed to evaluate the root system of two upland rice varieties, which exhibit contrasting behavior towards drought tolerance, and to identify the root features involved in the mechanism of drought escape in the tolerant variety.

\section{Materials and Methods}

Two experiments were performed under greenhouse and growth chamber conditions. The first aimed to identify the root angle and physiological features of rice varieties subjected to drought and control conditions. The second experiment aimed to characterize and indicate which root features were modified during drought-induced stress as compared to the control.

\section{Experiment $I$}

Upland rice varieties previously characterized as tolerant (Catetão) and susceptible (Mira) to drought stress (Ferreira, 2017) were used in this study. The experiment was conducted under greenhouse conditions. Rice seeds were initially washed in $2 \%$ sodium hypochlorite solution for 10 minutes. The seeds were germinated in a growth chamber at 500 $\mu$ mol photons $\mathrm{m}^{-2} \mathrm{~s}^{-1}, 12 \mathrm{~h}$ photoperiod and $70 \%$ humidity. At 10 days after germination (DAG), the seedlings were transferred to a greenhouse and conditioned in pots containing a basket full of soil from a Planosol. Two plants from each variety were grown into the basket. The basket was previously set up with a line to classify roots emerging from the upper and lower parts of the basket, as shallow or deep, according to the horizontal angle respective to the ground surface (Uga, 2012). The ranges of angles marked were: $0-30^{\circ} ; 30-60^{\circ}$, and $60-$ $90^{\circ}$. Five days after the transfer, the plants were fertilized with $20 \mathrm{~kg} \mathrm{ha}^{-1}$ of $\mathrm{N}$ in the form of urea and $20 \mathrm{~kg} \mathrm{ha}^{-1}$ of $\mathrm{K}_{2} \mathrm{O}$. The experimental design was completely randomized, using a $2 \times 2$ factorial scheme (varieties $\times$ drought stress conditions) with four replicates. The experiment was repeated twice to verify its reproducibility.

Water regimes were applied at 30 days after germination and consisted of a control treatment, where the moisture content was maintained close to field capacity $(0,02 \mathrm{MPa})$ and a moderate water stress treatment, which consisted of maintaining the water potential between 0.05 and $0.06 \mathrm{MPa}$. 
Control of soil water tension was performed by tensiometers installed in the columns at a depth of $30 \mathrm{~cm}$. Irrigation was performed daily by applying approximately $100 \mathrm{~mL}$ of water; this dose maintained the water tension in the desired range during the drought stress treatment. In the control experiment, soil water tension was maintained at field capacity. The plants were kept under drought stress for 14 days until harvest.

\section{Determination of root angle and physiological features}

At harvest time, the root system was carefully washed without being removed from the basket. The nodal roots which crossed the meshes in the different ranges of horizontal angles were counted. Ratio of deep rooting (RDR) is referred to the ratio of total number of roots that crossed the angles in the range of $60-90^{\circ}$ to the total number of roots that crossed all angle ranges. Plants were segmented into leaf, stem, and roots, and packed in paper bags for further analysis.

The relative water content (RWC, \%) was determined using samples of leaves (leaves +2 ). The samples were immersed in distilled water and kept at $4{ }^{\circ} \mathrm{C}$ in the dark for $24 \mathrm{~h}$, followed by determination of the turgid weight. The dry weight was obtained after drying the samples with forced air circulation at $60{ }^{\circ} \mathrm{C}$ for three days, according to Weatherley (1950). The electrolyte leakage (EL, \%) was determined according to Bajji, Kinet and Lutts (2002), using leaf disks from leaves +2 . Conductivity measurement was performed using a DDS-IIA conductivity meter (Shanghai Leici Instrument Inc., Shanghai, China). The relative electrolyte leakage was obtained by the division of the initial and final conductivity. Lipid peroxidation was determined according to Heath and Packer (1968) using samples of $0.2 \mathrm{~g}$ from leaves +2 . The content of thiobarbituric acid reactive substances (TBARS) was estimated using the molar extinction coefficient of $155 \mathrm{mM}^{-1} \mathrm{~cm}^{-1}$.

\section{Experiment II}

The experiment was conducted under growth chamber conditions $\left(500 \mu \mathrm{mol}\right.$ photons $\mathrm{m}^{-2} \mathrm{~s}^{-1} ; 12$ $\mathrm{h}$ photoperiod, $70 \%$ humidity, $28{ }^{\circ} \mathrm{C} / 26{ }^{\circ} \mathrm{C}$ day/ night temperatures). Rice seeds of Catetão and Mira varieties were initially disinfected in a $2 \%$ sodium hypochlorite solution for 10 minutes and washed repeatedly in distilled water. Seeds were placed on gauze in $1.7 \mathrm{~L}$ pots and allowed to germinate in distilled water in the growth chamber. Five days after germination (DAG) the plants were transferred to $700 \mathrm{~mL}$ pots (four plants per pot) and connected to a hydroponic system. The plants were cultivated with Hoagland solution (Hoagland \& Arnon, 1950) modified with $1 / 2$ IS (ionic strength) and $2.0 \mathrm{mM}$ of $\mathrm{N}\left(1.5 \mathrm{mM} \mathrm{NO}_{3}{ }^{-}\right.$and $\left.0.5 \mathrm{mM} \mathrm{NH}_{4}^{+}\right)$. At $10 \mathrm{DAG}$, the plants were subjected to control or drought stress conditions for 14 days. The nutritive solution was replaced every 3 days and the $\mathrm{pH}$ maintained at 5.7. Drought stress was initiated by the addition of $20 \%$ polyethylene glycol 6000 (PEG) in the nutritive solution, which resulted in approximately - 0.82 MPa of osmotic pressure (Li, Zang, Deng, \& Wang, 2011). At $24 \mathrm{DAG}$, the root system was harvested and stored in $50 \%$ ethanol for further analysis. The experimental design was completely randomized with four replicates. The experiment was repeated twice to verify its reproducibility.

The root system from each variety was scattered in a vessel containing distilled water and scanned at $600 \mathrm{dpi}$ using the Expression 11000XL scanner (Epson, Long Beach, CA). The images obtained were used to calculate the root features (volume, length, number of primary and lateral roots and number of root tips) through the Rootgraph program (Cai et al., 2015).

\section{Statistical analysis}

The data obtained in both experiments were first subjected to normality and variance homogeneity tests, followed by analysis of variance (ANOVA). The means were compared using Tukey's test at $\mathrm{p} \leq$ 0.05 of significance using SISVAR software. 


\section{Results}

The first experiment evaluated shoot and root dry weights, number of roots that crossed the mesh in the angle ranges $0-30^{\circ}, 30-60^{\circ}$, and $60-90^{\circ}$, as well as the RDR for both varieties subjected to control and drought stress treatments under greenhouse conditions. While both shoot and root dry weights in both varieties were reduced under drought stress, Catetão maintained a greater biomass when compared to Mira. The root/shoot ratio remained stable in Catetão, while a significant reduction was observed in Mira (Table 1).

Table 1

Shoot and root dry weights and root/shoot ratio from Catetão and Mira varieties subjected to control and drought treatment for 14 days

\begin{tabular}{|c|c|c|c|c|c|c|}
\hline \multirow{2}{*}{ Varieties } & \multicolumn{2}{|c|}{ Shoot } & \multicolumn{2}{|c|}{ Root } & \multicolumn{2}{|c|}{ Root/Shoot } \\
\hline & Cont. & Dro. & Cont. & Dro. & Cont. & Dro. \\
\hline & \multicolumn{2}{|c|}{$\mathrm{g} \mathrm{pot}^{-1}$} & \multicolumn{2}{|c|}{$\mathrm{g} \mathrm{pot}^{-1}$} & \multicolumn{2}{|c|}{$\mathrm{g} \mathrm{pot}^{-1}$} \\
\hline Catetão & $16,09 \mathrm{Aa}$ & $9,18 \mathrm{Ba}$ & $14,62 \mathrm{Aa}$ & $9,87 \mathrm{Ba}$ & $0,90 \mathrm{Aa}$ & $1,07 \mathrm{Aa}$ \\
\hline Mira & $10,60 \mathrm{Ab}$ & $7,58 \mathrm{Bb}$ & $10,98 \mathrm{Ab}$ & $4,27 \mathrm{Bb}$ & $1,05 \mathrm{Aa}$ & $0,55 \mathrm{Bb}$ \\
\hline C.V\% & \multicolumn{2}{|c|}{7,31} & \multicolumn{2}{|c|}{14,52} & \multicolumn{2}{|c|}{16,32} \\
\hline
\end{tabular}

${ }^{a}$ Means followed by the same capital letter between treatments and lowercase between varieties do not differ statistically by the Tukey's test at $\mathrm{p} \leq 0.05$ of significance. Cont. $=$ Control; Dro. $=$ Drought; Coefficient of Variation $=$ C.V $\%$.

The root systems of the Catetão and Mira varieties were photographed (Figure 1). A clear reduction was observed in the root biomass from both varieties subjected to drought stress (Figure
1B and D). In order to quantify the number of roots that crossed the basket mesh in the different angle ranges, the nodal roots were counted and the ratio of deep rooting was determined (Table 2).

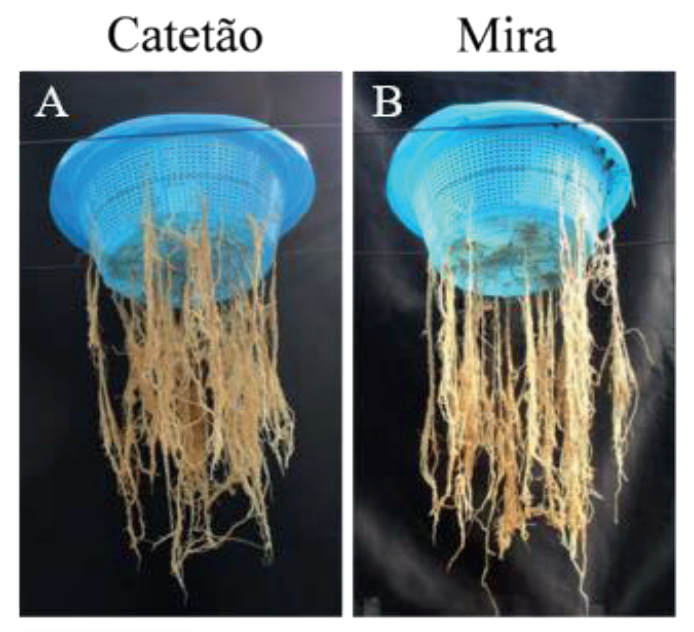

Control

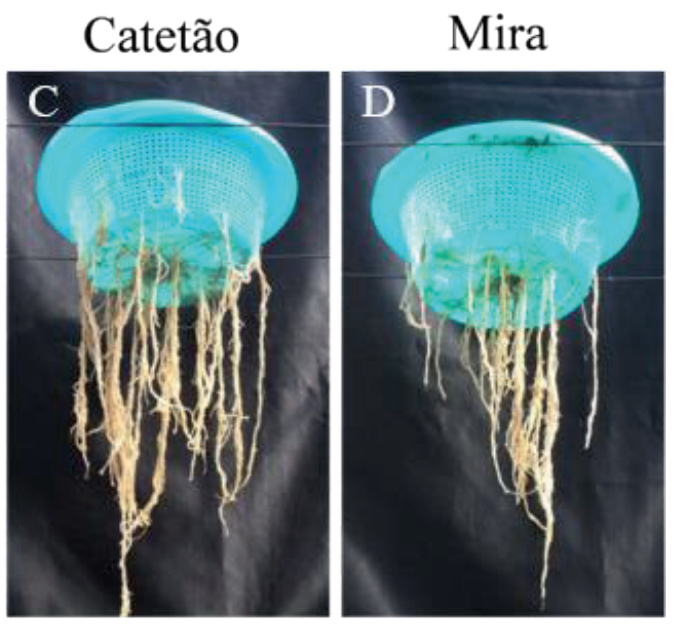

Drought

Figure 1. Morphology of Catetão and Mira roots that crossed the mesh at the angles of $0-30^{\circ} ; 30-60^{\circ}$ and $60-90^{\circ}$ when subjected to control and drought treatments for 14 days. 


\section{Table 2}

Number of roots from Catetão and Mira varieties that crossed the mesh at the angles of $0-30^{\circ} ; 30-60^{\circ}$ and $60-90^{\circ}$ when subjected to control and drought treatment during 14 days

\begin{tabular}{|c|c|c|c|c|c|c|}
\hline \multirow{2}{*}{ Varieties } & \multicolumn{2}{|c|}{$0-30^{\circ}$} & \multicolumn{2}{|c|}{$30-60^{\circ}$} & \multicolumn{2}{|c|}{$60-90^{\circ}$} \\
\hline & Cont. & Dro. & Cont. & Dro. & Cont. & Dro. \\
\hline & \multicolumn{2}{|c|}{ Number of roots } & \multicolumn{2}{|c|}{ Number of roots } & \multicolumn{2}{|c|}{ Number of roots } \\
\hline Catetão & $27,0 \mathrm{Aa}$ & $16,7 \mathrm{Ba}$ & $37,3 \mathrm{Aa}$ & $25,3 \mathrm{Ba}$ & $26,0 \mathrm{Ba}$ & $33,3 \mathrm{Aa}$ \\
\hline Mira & $27,7 \mathrm{Aa}$ & $7,0 \mathrm{Bb}$ & $32,0 \mathrm{Ab}$ & $11,7 \mathrm{Bb}$ & $16,0 \mathrm{Ab}$ & $4,3 \mathrm{Bb}$ \\
\hline C.V\% & \multicolumn{2}{|c|}{15,44} & \multicolumn{2}{|c|}{12,24} & \multicolumn{2}{|c|}{9,45} \\
\hline
\end{tabular}

${ }^{a}$ Means followed by the same capital letter between treatments and lowercase between varieties do not differ statistically by the Tukey's test at $\mathrm{p} \leq 0.05$ of significance. Cont. $=$ Control; Dro. $=$ Drought; Coefficient of Variation $=$ C.V\%.

At the $0-30^{\circ}$ angle, Catetão and Mira varieties did not differ among themselves when subjected to control conditions (Table 2). Under drought conditions, Catetão displayed a slight root reduction of approximately 38\%, while Mira exhibited $74 \%$ root reduction. At the $30-60^{\circ}$ angle, Catetão produced a higher number of roots under the control treatment as compared to Mira. A reduction in root number was however observed in both varieties when subjected to drought stress. The ratio of reduction was as observed for the previous range.
At the $60-90^{\circ}$ angle, Catetão displayed a significant increase in root number under drought stress (Table 2), while root number in Mira reduced drastically by approximately $73 \%$. The RDR was calculated for both varieties based on these results, as shown in Figure 2. Catetão showed an increase of $53 \%$ in RDR when subjected to drought stress, while Mira remained stable.

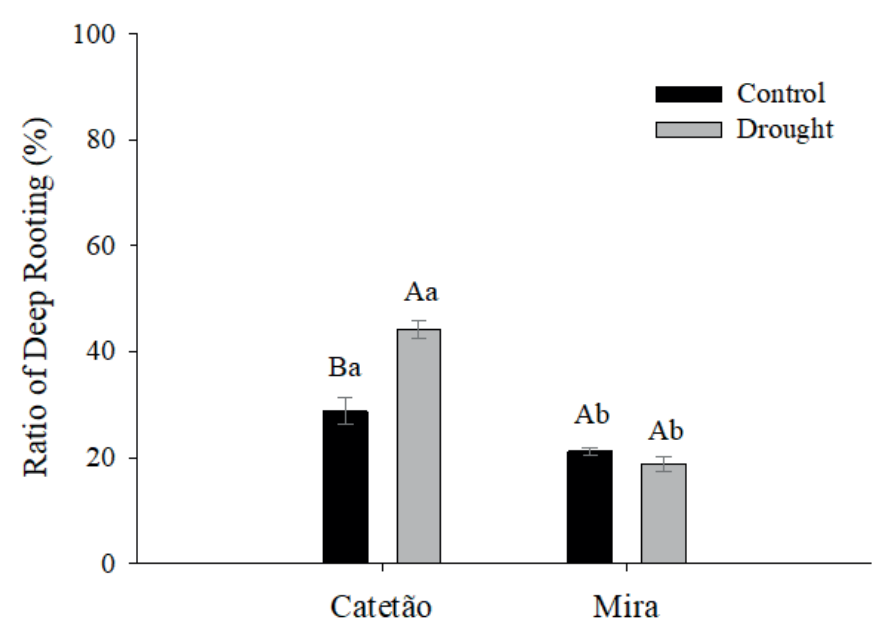

Figure 2. Ratio of deep rooting from Catetão and Mira varieties when subjected to control and drought treatments for 14 days. Means followed by the same capital letter between treatments and lowercase between varieties do not differ statistically by the Tukey's test at $\mathrm{p} \leq 0.05$ of significance. Coefficient of variation, C.V $\%=8,93$. 
Physiological features were determined for each variety from leaves +2 from each variety subjected to control and drought conditions (Figure 3). Relative water content decreased in both varieties under drought stress conditions (Figure 3A). However, this decrease was significantly higher in Mira (24\%), while a reduction of approximately $12 \%$ was observed in Catetão. An increase in electrolyte leakage (EL) was observed only in the Mira variety when subjected to drought stress and a similar trend was also observed in lipid peroxidation, represented by malondialdehyde (MDA) concentrations. EL and MDA concentration remained stable in Catetão (Figures 3B and C).

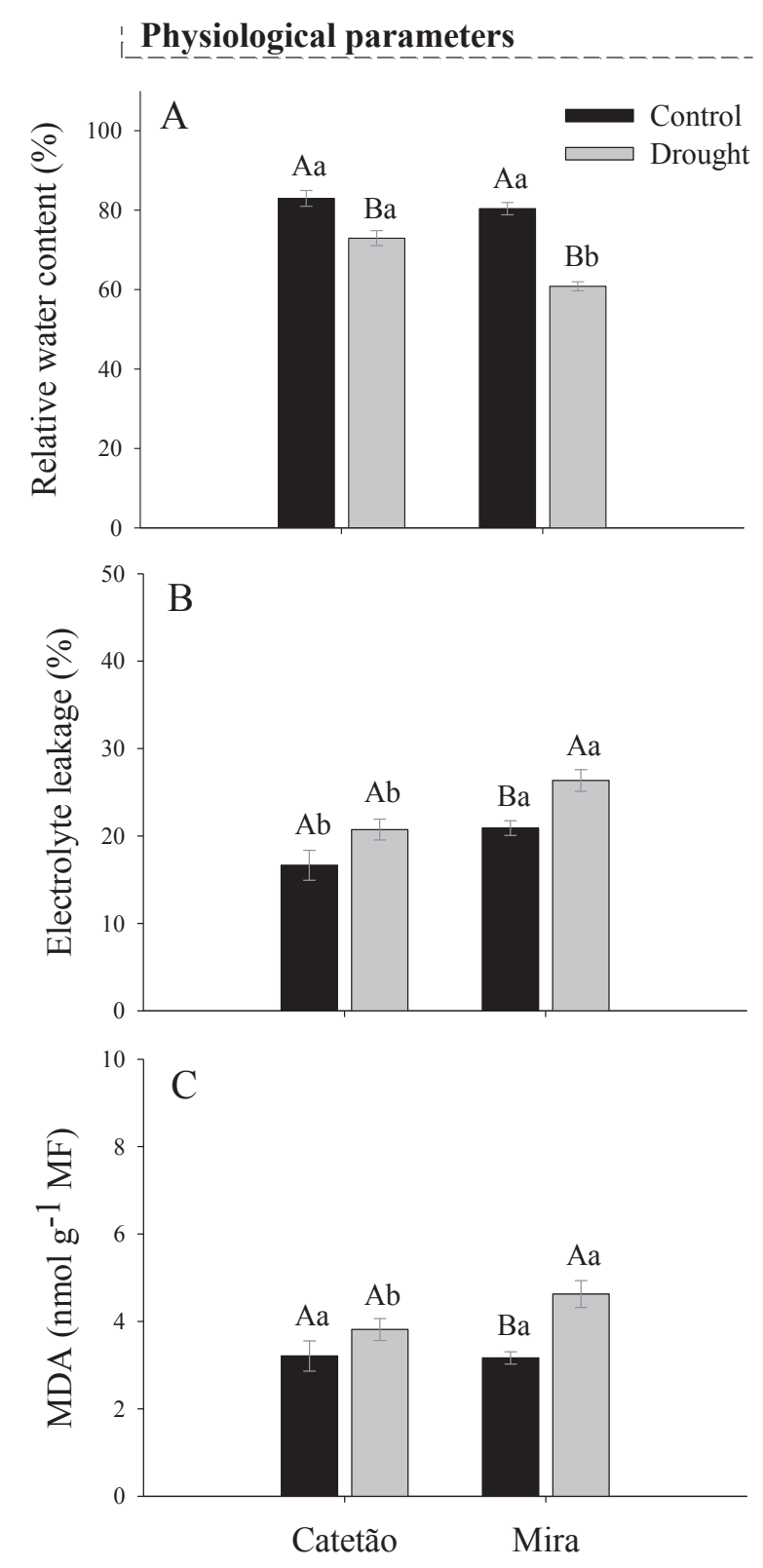

Figure 3. Relative water content (RWC, \%) (A), Electrolyte leakage (EL, \%) (B) and malondialdehyde in rice leaves +2 (MDA, $\left.\mathrm{g}^{-1} \mathrm{MF}\right)(\mathrm{C})$ from Catetão and Mira varieties subjected to control and drought treatment for 14 days. Error bars indicate the means of four replicates. Means followed by the same capital letter between treatments and lowercase between varieties do not differ statistically by the Tukey's test at $\mathrm{p} \leq 0.05$ of significance. Coefficient of variation, C.V $\%=2,82(\mathrm{RWC}), \mathrm{C} . \mathrm{V} \%=6,43(\mathrm{EL})$ and $\mathrm{C} . \mathrm{V} \%=10,88(\mathrm{MDA})$. 
The second experiment evaluated the root system of plants subjected to osmotic stress. Both varieties treated with 20\% PEG 6000 exhibited a reduced biomass of the root system and, consequently, a reduction in almost every root feature evaluated. Despite the observed reduced growth, the volume and total length of primary roots were increased in Catetão, compared to Mira, during drought stress treatment (Figures 4A and B). The volume of primary roots in Catetão more than doubled, when compared to Mira (Figure 4A).

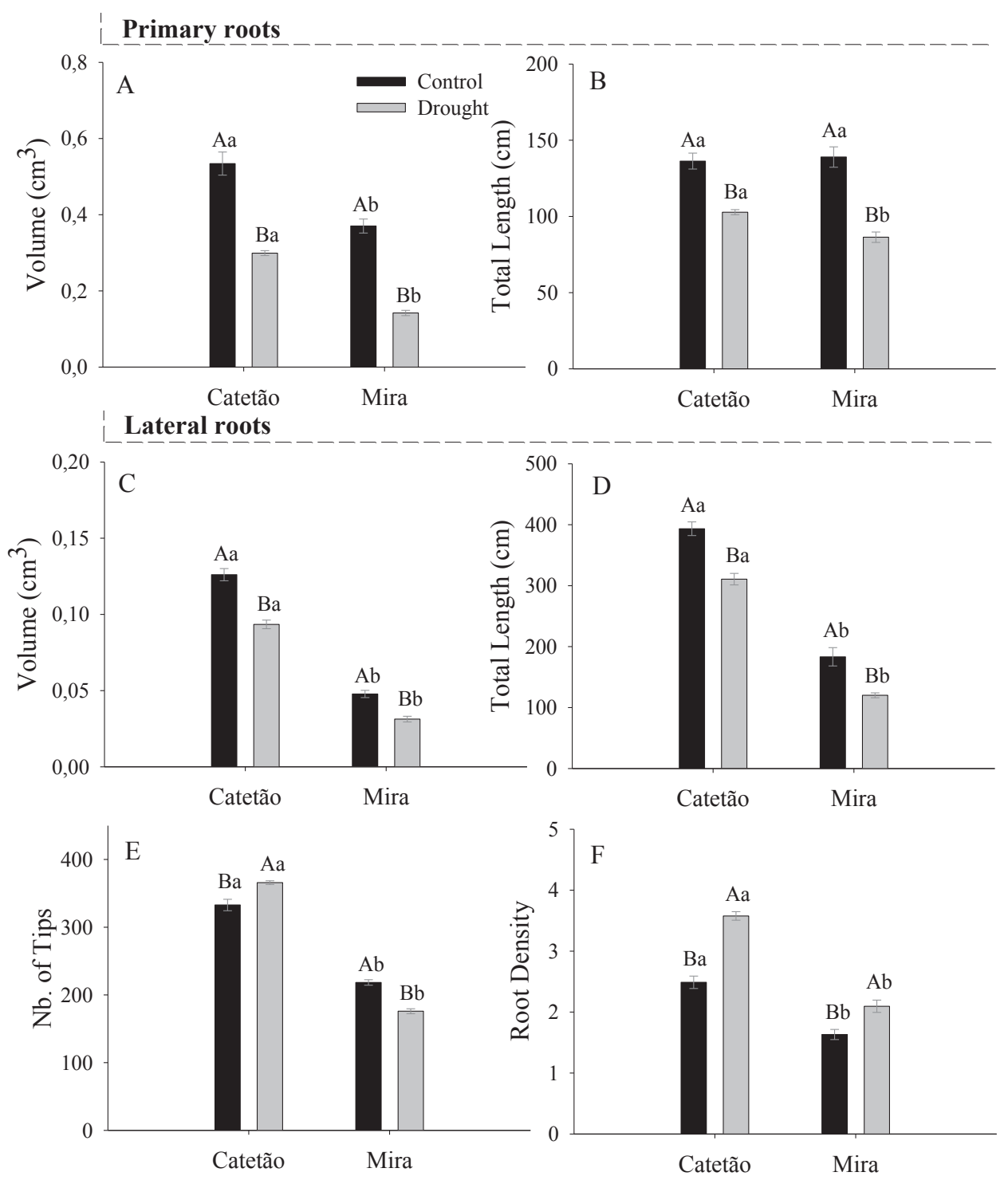

Figure 4. Root features from Catetão and Mira varieties subjected to control and drought treatments for 7 days. Drought stress was applied with $20 \%$ PEG 6000 . Lateral root density represents the ratio between root tips and total length for each variety. Means followed by the same uppercase letter between treatments and lowercase letter between varieties do not differ statistically by the Tukey's test at $\mathrm{p} \leq 0.05$ significance. Coefficients of variation from primary roots are C.V $\%=6,06$ (volume) and C.V $\%=6,75$ (total length). Coefficients of variation from lateral roots are C.V $\%=9,60$ (volume); C.V \% = 3,86 (total length); C.V \% $=2,80$ (number of tips) and C.V \% $=7,18$ (root density). 
The lateral roots showed a reduction in volume and total length for both varieties subjected to drought stress, compared with the control condition (Figures 4C and D). However, under drought stress, Catetão behaved differently by increasing its root volume and total root length, as compared to Mira. Intriguingly, Catetão showed a greater capability to branch under drought stress, whereas Mira exhibited an opposite behavior (Figure 4E). Lateral root density, which represents the ratio of the number of tips to the total length of roots, increased in both varieties. However, this increase was significantly higher for the Catetão variety (Figure 4F).

\section{Discussion}

Upland rice varieties tolerant to drought stress have been studied by several research groups in Brazil and around the world. Terra, Leal, Borém and Rangel (2013), identified a line named 51, obtained from crossing Bico Ganga Curto with Chorinho cultivars, to be tolerant to drought stress. Productivity in this line remained stable when subjected to control and drought conditions. Another study was conducted by Tonello et al. (2016), where three upland rice varieties subjected to different climate and soil variations were evaluated over five agricultural years. This study identified BRS Primavera cultivar as the most stable and productive in successive years of cultivation under different environmental conditions. The analysis of yield characteristics has been performed in these studies and can be considered essential in identifying drought tolerant varieties. Currently, however, several studies have attempted to determine the characteristics directly involved in drought tolerance. Among them, root architecture diversity in rice has been a solid basis for drought tolerance research (Wu \& Cheng, 2014).

Root biomass is an important yield predictor in rice and is directly responsible for achieving a greater tolerance to drought stress (Comas, Becker, Cruz, Byrne, \& Dierig, 2013). The observed results suggest that Catetão has the potential to invest in its root system when under drought stress, a characteristic which may contribute to the deepening of the root system in the soil profile (Figure 1 and Table 2).

The hypothesis of root deepening was verified by separating the roots that crossed the mesh at three classes of root angles, according to the method developed by Uga (2012). Catetão showed an increase in the number of roots that crossed the mesh in the range of $60-90^{\circ}$, as well as in the RDR (Figure 2). These two features indicate that this variety produced deeper roots at a smaller angle in relation to the main root axis. A deep root system is currently considered as one of the most promising mechanisms of drought escape. Manschadi, Christopher, deVoil and Hammer (2006), observed that root architecture differed markedly among analyzed wheat genotypes. SeriM82 presented with a more uniform rooting pattern as well as greater root length and depth when compared to the standard wheat variety Hartog. This characteristic could potentially contribute to increased access to water from deep soil layers during the grain filling phase in drought tolerant varieties.

Uga, Kitomi, Ishikawa and Yano (2015), have demonstrated that root angle determination and evaluation is an important method in the identification of rice and maize genotypes tolerant to drought stress. A study on rice by Kato, Abe, Kamoshita and Yamagishi (2006), investigated genotypic variation in root growth angle. A pool of 12 upland rice cultivars was analyzed using the basket method under irrigated conditions. The results showed that constitutive root growth, which is genetically determined, is important for deep root development under intermittent drought conditions during the reproductive stage.

In the present study, Catetão exhibited constitutive root growth and improved deep root ratio under drought stress. This behavior favors a plastic root response by increasing the number of roots that cross the mesh at $60-90^{\circ}$, compared with 
other angle ranges, in response to drought. Similar results were also observed by Uga, Okuno and Yano (2011), as well as, by Rich and Watt (2013).

The varieties were evaluated for RWC, EL and MDA (Figure 3). The reduction of RWC is common in plants subjected to drought stress, as observed by Xiong et al. (2012) and Goodarzian Ghahfarokhi et al. (2015). However, tolerant varieties had a tendency to present a small reduction of this parameter, as observed for Catetão.

The stability of EL and MDA contributed to the maintenance of membrane integrity and to a low production of reactive oxygen species (ROS). This result is in agreement with the available literature on different plant species, which reports that plants with better water status have a lower rate of membrane damage and lipid peroxidation (Basu, Roychoudhury, Saha, \& Sengupta, 2010; Mirzaee, Moeini, \& Ghanati, 2013). The recorded physiological features demonstrated that the Catetão variety developed mechanisms to tolerate drought stress, while Mira displayed a higher susceptibility towards drought conditions.

The determination of root features has been of fundamental importance to quantify the size of the root system and thus evaluate the capacity of water and nutrient uptake by plants (Kano, Inukai, Kitano, \& Yamauchi, 2011). Previous studies have suggested that increased lateral root emission under stress could be important features involved in drought tolerance (Gowda, Henry, Yamauchi, Shashidhar, \& Serraj, 2011; Comas et al., 2013). Other studies using transgenic lines have also showed how these features are fundamental for increasing drought stress tolerance in rice and maintain production in adverse environments (Werner et al., 2010; Redillas et al., 2012).

Increasing knowledge on root attributes that may affect water uptake under stress may help breeders elucidate genotype versus environment interactions and point to important characteristics related to drought tolerance and crop production (Serraj et al.,
2011; Ali et al., 2015). Henry, Cal, Batoto, Torres and Serraj (2012), have demonstrated that the increase in lateral root emission could partly explain the differences in water uptake by tolerant varieties subjected to drought stress. Rice improvement programs have determined that deep rooting is a target trait (Gowda et al., 2011).

The first experiment investigated the root system architecture in soil conditions using the basket method. The varieties showed marked differences in their respective root system architecture under drought stress. We also analyzed the physiological features, which suggest that the Catetão variety is more tolerant to drought stress. From the results obtained, we carried out a second experiment, which aimed to further analyze the alterations observed in the root system, by promoting drought stress using $20 \%$ PEG in the nutritive solution. This experiment investigated the root system and quantified different root features (Figure 4). The Catetão variety was shown to have a naturally greater root biomass from primary and lateral roots and is also able to increase lateral root emission under drought stress. The diversity in root morphology and architecture observed in our study is of paramount importance for plant survival, maintenance of membrane stability, and productivity under adverse environmental conditions.

\section{Conclusions}

The Catetão variety demonstrated the ability to deepen their root system and displayed more favorable physiological features during drought stress. The increase in lateral root emission and root density in Catetão could contribute to the mechanism of drought escape.

The Mira variety displayed unfavorable physiological features and a reduction in all analyzed root features during drought stress.

The combination of high RDR and lateral root emission observed in Catetão under drought stress 
may be considered important predictors for the selection of drought tolerant varieties.

\section{Acknowledgements}

The authors acknowledge the Coordenação de Aperfeiçoamento de Pessoal de Nível Superior (CAPES), the Conselho Nacional de Desenvolvimento Científico e Tecnológico (CNPq) and Fundação de Amparo à Pesquisa do Estado do Rio de Janeiro (FAPERJ) for the grants.

\section{References}

Ali, M. L., Luetchens, J., Nascimento, J., Shaver, T. M., Kruger, G. R., \& Lorenz, A. J. (2015). Genetic variation in seminal and nodal root angle and their association with grain yield of maize under waterstressed field conditions. Plant and Soil, 397(1-2), 213-225. doi: 10.1007/s11104-015-2554-x

Bajji, M., Kinet, J. M., \& Lutts, S. (2002). The use of the electrolyte leakage method for assessing cell membrane stability as a water stress tolerance test in durum wheat. Plant Growth Regulation, 36(1), 6170. doi: 10.1023/A:1014732714549

Basu, S., Roychoudhury, A., Saha, P. P., \& Sengupta, D. N. (2010). Differential antioxidative responses of indica rice cultivars to drought stress. Plant Growth Regulation, 60(1), 51. doi: 10.1007/s10725-0099418-4

Biscarini, F., Cozzi, P., Casella, L., Riccardi, P., Vattari, A., Orasen, G., ... \& Cattivelli, L. (2016). Genomewide association study for traits related to plant and grain morphology, and root architecture in temperate rice accessions. PLoS One, 11(5), e0155425. doi: 10.1371/journal.pone.0155425

Bishwajit, G., Sarker, S., Kpoghomou, M. A., Gao, H., Jun, L., Yin, D., \& Ghosh, S. (2013). Selfsufficiency in rice and food security: a South Asian perspective. Agriculture \& Food Security, 2(1), 10. doi: $10.1186 / 2048-7010-2-10$

Bouman, B. A. M., Peng, S., Castaneda, A. R., \& Visperas, R. M. (2005). Yield and water use of irrigated tropical aerobic rice systems. Agricultural Water Management, 74(2), 87-105. doi: 10.1016/j. agwat.2004.11.007

Cai, J., Zeng, Z., Connor, J. N., Huang, C. Y., Melino, V., Kumar, P., \& Miklavcic, S. J. (2015). RootGraph: a graphic optimization tool for automated image analysis of plant roots. Journal of Experimental Botany, 66(21), 6551-6562. doi: 10.1093/jxb/erv359

Comas, L., Becker, S., Cruz, V. M. V., Byrne, P. F., \& Dierig, D. A. (2013). Root traits contributing to plant productivity under drought. Frontiers in Plant Science, 4(442), 1-16. doi: 10.3389/fpls.2013.00442

Cramer, G. R., Urano, K., Delrot, S., Pezzotti, M., \& Shinozaki, K. (2011). Effects of abiotic stress on plants: a systems biology perspective. BMC Plant Biology, 11(1), 163-177. doi: 10.1186/1471-222911-163

Ferreira, L. M. (2017). Características morfológicas, fisiológicas e transcriptoma em variedades de arroz (Oryza sativa L.) contrastantes quanto a tolerância ao estresse hídrico. Tese de doutorado, Universidade Federal Rural do Rio de Janeiro, Seropédica, RJ, Brasil.

Gao, Y., Xie, Y., Jiang, H., Wu, B., \& Niu, J. (2014). Soil water status and root distribution across the rooting zone in maize with plastic film mulching. Field Crops Research, 156(1), 40-47. doi: 10.1016/j. fcr.2013.10.016

Goodarzian Ghahfarokhi, M., Mansurifar, S., Taghizadeh-Mehrjardi, R., Saeidi, M., Jamshidi, A. M., \& Ghasemi, E. (2015). Effects of drought stress and rewatering on antioxidant systems and relative water content in different growth stages of maize (Zea mays L.) hybrids. Archives of Agronomy and Soil Science, 61(4), 493-506. doi: $10.1080 / 03650340.2014 .943198$

Gowda, V. R., Henry, A., Yamauchi, A., Shashidhar, H. E., \& Serraj, R. (2011). Root biology and genetic improvement for drought avoidance in rice. Field Crops Research, 122(1), 1-13. doi: 10.1016/j. fcr.2011.03.001

Heath, R. L., \& Packer, L. (1968). Photoperoxidation in isolated chloroplasts: I. Kinetics and stoichiometry of fatty acid peroxidation. Archives of Biochemistry and Biophysics, 125(1), 189-198. doi: 10.1016/00039861(68)90654-1

Henry, A. (2013). IRRI's drought stress research in rice with emphasis on roots: accomplishments over the last 50 years. Plant Root, 7(1), 92-106. doi: 10.3117/ plantroot.7.92

Henry, A., Cal, A. J., Batoto, T. C., Torres, R. O., \& Serraj, R. (2012). Root attributes affecting water uptake of rice (Oryza sativa) under drought. Journal of Experimental Botany, 63(13), 4751-4763 doi: $10.1093 / \mathrm{jxb} / \mathrm{ers} 150$ 
Hoagland, D. R., \& Arnon, D. I. (1950). The waterculture method for growing plants without soil. Circular. (2nd ed.). Berkeley: California Agricultural Experiment Station

Kano, M., Inukai, Y., Kitano, H., \& Yamauchi, A. (2011). Root plasticity as the key root trait for adaptation to various intensities of drought stress in rice. Plant and Soil, 342(1-2), 117-128. doi: 10.1007/s11104-0100675-9

Kato, Y., Abe, J., Kamoshita, A., \& Yamagishi, J. (2006). Genotypic variation in root growth angle in rice (Oryza sativa L.) and its association with deep root development in upland fields with different water regimes. Plant and Soil, 287(1-2), 117-129. doi: 10.1007/s11104-006-9008-4

Kell, D. B. (2011). Breeding crop plants with deep roots: their role in sustainable carbon, nutrient and water sequestration. Annals of Botany, 108(3), 407-418. doi: $10.1093 / \mathrm{aob} / \mathrm{mcr} 175$

Lawlor, D. W., \& Cornic, G. (2002). Photosynthetic carbon assimilation and associated metabolism in relation to water deficits in higher plants. Plant, Cell \& Environment, 25(2), 275-294. doi: 10.1046/j.00168025.2001.00814.x

Li, H. W., Zang, B. S., Deng, X. W., \& Wang, X. P. (2011). Overexpression of the trehalose-6-phosphate synthase gene OsTPS1 enhances abiotic stress tolerance in rice. Planta, 234(5), 1007-1018. doi: 10.1007/s00425-011-1458-0

Lian, H. L., Yu, X., Ye, Q., Ding, X. S., Kitagawa, Y., Kwak, S. S.,.. \& Tang, Z. C. (2004). The role of aquaporin RWC3 in drought avoidance in rice. Plant and Cell Physiology, 45(4), 481-489. doi: 10.1093/ $\mathrm{pcp} / \mathrm{pch} 058$

Manschadi, A. M., Christopher, J., deVoil, P., \& Hammer, G. L. (2006). The role of root architectural traits in adaptation of wheat to water-limited environments. Functional Plant Biology, 33(9), 823-837. doi: 10.1071/FP06055

Mirzaee, M., Moeini, A., \& Ghanati, F. (2013). Effects of drought stress on the lipid peroxidation and antioxidant enzyme activities in two canola (Brassica napus L.) cultivars. Journal of Agricultural Science and Technology, 15(3), 593-602

Nakandalage, N., Nicolas, M., Norton, R. M., Hirotsu, N., Milham, P. J., \& Seneweera, S. (2016). Improving rice zinc biofortification success rates through genetic and crop management approaches in a changing environment. Frontiers in Plant Science, 7(1), 764. doi: 10.3389/fpls.2016.00764
Ortiz, T. A., Urbano, M. R., \& Takahashi, L. S. A. (2019). Effects of water deficit and $\mathrm{pH}$ on seed germination and seedling development in Cereus jamacaru. Semina: Ciências Agrárias, 40(4), 1379-1392. doi: 10.5433/1679-0359.2019v40n4p1379

O'Toole, J. C., \& Chang, T. T. (1979). Drought resistance in cereals-rice: a case study. In H. Mussell \& R. C. Staples (Eds.), Stress physiology in crop plants (pp. 373-405). New York, NY: Wiley Interscience.

Paez-Garcia, A., Motes, C. M., Scheible, W. R., Chen, R., Blancaflor, E. B., \& Monteros, M. J. (2015). Root traits and phenotyping strategies for plant improvement. Plants, 4(2), 334-355. doi: 10.3390/ plants4020334

Passioura, J. B. (1997). Drought and drought tolerance. In Drought tolerance in higher plants. Genetical, physiological and molecular biological analysis (pp. 1-5). Dordrecht, Dordr: Kluwer Academic Publisher.

Redillas, M. C., Jeong, J. S., Kim, Y. S., Jung, H., Bang, S. W., Choi, Y. D.,... \& Kim, J. K. (2012). The overexpression of OsNAC9 alters the root architecture of rice plants enhancing drought resistance and grain yield under field conditions. Plant Biotechnology Journal, 10(7), 792-805. doi: 10.1111/j.1467-7652.2012.00697.x

Rich, S. M., \& Watt, M. (2013). Soil conditions and cereal root system architecture: review and considerations for linking Darwin and Weaver. Journal of Experimental Botany, 64(5), 1193-1208. doi: 10.1093/jxb/ert043

Rogers, E. D., Monaenkova, D., Mijar, M., Nori, A., Goldman, D. I., \& Benfey, P. N. (2016). X-ray computed tomography reveals the response of root system architecture to soil texture. Plant Physiology, 171(3), 2028-2040. doi: 10.1104/pp.16.00397

Seck, P. A., Diagne, A., Mohanty, S., \& Wopereis, M. C. (2012). Crops that feed the world 7: Rice. Food Security, 4(1), 7-24. doi: 10.1007/s12571-012-01681

Serraj, R., McNally, K. L., Slamet-Loedin, I., Kohli, A., Haefele, S. M., Atlin, G., \& Kumar, A. (2011). Drought resistance improvement in rice: an integrated genetic and resource management strategy. Plant Production Science, 14(1), 1-14. doi: 10.1626/pps.14.1

Suralta, R. R., Kano-Nakata, M., Niones, J. M., Inukai, Y., Kameoka, E., Tran, T. T., \& Yamauchi, A. (2018). Root plasticity for maintenance of productivity under abiotic stressed soil environments in rice: Progress and prospects. Field Crops Research, 220(1), 57-66. doi: 10.1016/j.fcr.2016.06.023 
Tardieu, F., Draye, X., \& Javaux, M. (2017). Root water uptake and ideotypes of the root system: whole-plant controls matter. Vadose Zone Journal, 16(9), 1-10. doi: 10.2136/vzj2017.05.0107

Terra, T. G. R., Leal, T. C. A. B., Borém, A., \& Rangel, P. H. N. (2013). Tolerância de linhagens de arroz de terras altas à seca. Pesquisa Agropecuária Tropical, 43(2), 201-208. doi: 10.1590/S198340632013000200013

Tonello, L. P., Oliveira Tavares, T. C. de, Oliveira Rocha, R. de, Santos, G. R. dos, Sousa, S. A. de, \& Fidelis, R. R. (2016). Agronomic performance of upland rice cultivars in the southern region of the state of Tocantins. Semina: Ciências Agrárias, 37(4), 16991708. doi: 10.5433/1679-0359.2016v37n4p1699

Uga, Y. (2012). Quantitative measurement of root growth angle by using the basket method. Methodologies for root drought studies in rice. The Philippines: International Rice Research Institute.

Uga, Y., Kitomi, Y., Ishikawa, S., \& Yano, M. (2015). Genetic improvement for root growth angle to enhance crop production. Breeding Science, 65(2), 111-119. doi: 10.1270/jsbbs.65.111

Uga, Y., Okuno, K., \& Yano, M. (2011). Dro1, a major QTL involved in deep rooting of rice under upland field conditions. Journal of Experimental Botany, 62(8), 2485-2494. doi: 10.1093/jxb/erq429
Weatherley, P. (1950). Studies in the water relations of the cotton plant: I. The field measurement of water deficits in leaves. New Phytologist, 49(1), 81-97. doi: 10.1111/j.1469-8137.1950.tb05146.x

Werner, T., Nehnevajova, E., Köllmer, I., Novák, O., Strnad, M., Krämer, U., \& Schmülling, T. (2010). Root-specific reduction of cytokinin causes enhanced root growth, drought tolerance, and leaf mineral enrichment in Arabidopsis and tobacco. The Plant Cell, 22(12), 3905-3920. doi: 10.1105/ tpc.109.072694

Wu, W., \& Cheng, S. (2014). Root genetic research, an opportunity and challenge to rice improvement. Field Crops Research, 165(1), 111-124. doi: 10.1016/j. fcr.2014.04.013

Xiong, J., Zhang, L., Fu, G., Yang, Y., Zhu, C., \& Tao, L. (2012). Drought-induced proline accumulation is uninvolved with increased nitric oxide, which alleviates drought stress by decreasing transpiration in rice. Journal of Plant Research, 125(1), 155-164. doi: 10.1007/s10265-011-0417-y 
